\title{
IMPROVING STUDENTS' ABILITY IN WRITING NARRATIVE TEXTS BY IMPLEMENTING PICTURE SERIES
}

\author{
Fifin Naili Rizkiyah ${ }^{1}$ \\ IKIP PGRI Jember \\ phiefin@gmail.com ${ }^{1}$ \\ Submit, 28-07-2018 Accepted, 25-12-2018 Publish, 25-12-2018
}

\begin{abstract}
This study was aimed at finding out whether the implementation of picture series strategy can improve the ability of the students in writing narrative text. The research design was collaborative action research which consisted of two cycles, in where cycle 1 consisted of three meetings and cycle 2 consisted of four meetings. A cycle consisted of four steps namely: planning the action, acting on the plan, observing the action and reflecting on the observation. The subject of the study was the 34 students. The instruments used to collect data were observation checklist, field notes, questionnaires, scoring rubrics and the students' writings. The data from the observation, scoring rubrics and questionnaires were analyzed and the results are presented in the form of tables and description, while the data gained from the field notes and the students' writings were analyzed and reported descriptively. The result of the study showed that the picture series effectively improved the students' ability in writing narrative texts. All students had reached the minimum score of 3 . Moreover, the majority of the students gave positive responses towards the implementation of picture series, in the case that $70 \%$ of the students showed excitement. Furthermore, they found that picture series is interesting, easy to understand, moreover, it helped them to organize paragraphs and develop ideas in writing narrative texts.
\end{abstract}

Keywords: picture series, writing ability, narrative text.

\section{INTRODUCTION}

In this era, English became increasingly important to master. English is a global language used by the majority of people around the world, whether as a first or second language. Many countries include English as one of the lessons taught in educational institutions. English is the key to mastering all aspects such as science, technology, economics and culture. The purpose of learning English is the mastery of the four language skills namely listening, reading, speaking, and writing. Productive skills are clearly more difficult than receptive skills. Widiati and Cahyono (2006:139) state that writing is the most complicated skill compared 
to the other three skills. Many students often complain about how difficult it is to write in a foreign language, even Blanchard and Root (2003:1) state that basically writing is difficult even in its own language. So it is natural that writing in a foreign language will become more complicated.

Students often have difficulty on how to put ideas in writing. They also have problems with vocabulary limitations. In addition, grammar issues should also be faced in writing English. The above problems are now faced by students of class $\mathrm{C}$ who took English II course which is the subject of this research. The writer took this subject in his research because she has already known the subject as she taught at IKIP PGRI Jember so that has understood well the strengths and weaknesses of students in learning English. The narrative is chosen as the genre in this study because the subject of this research is students of early childhood educataion where narrative or story is one of the most effective method often used in teaching young children. As early childhood teacher candidates, of course, the students must be equipped with knowledge and experience that will be useful later if they have taught in early childhood education.

Starting from the problems above, the author wants to find the right strategy so as to improve the ability to write a narrative of early childhood education students who were taking English II. Picture series is considered appropriate to stimulate students in developing ideas in writing narrative. The author's considerations why use picture seriess are: first, pictures display visual frames that represent places, objects and people so as to stimulate students' brains in composing and pouring ideas; second, pictures can provoke the creativity of students in thinking because the series can lead the students to understand the story; thirdly, pictures are always interesting to everyone, especially beginners and children Wright (1992:2).

Picture series serve as media in guiding students to write narrative text. The pictures used are not just any series of images. There are several criteria for picture seriess used by the researcher. First, the pictures used can achieve the learning objectives. The pictures' content should be adjusted to the student's needs. More importantly, the pictures should be clear, easy to understand and certainly interesting so that pictures as media are really effective.

Some researches on the use of picture series in writing narrative text have also been done. Ariani (2010:89) used a series of picture to write narrative texts on the 3rd semester students of French Language Education Program. The conclusions of her research indicate that the media of picture series are effective in improving students' writing skill in the third semester students of French Language Education BSA FBS UNNES. Hasanah (2008:90) used picture sequences to improve the writing ability of grade VIII students of SMPN 6 Malang. Overall, the results of the study show that picture sequences can help 
students give an idea of writing stories and composing them coherently. Nitalinawati (2009:34) conducted research on wordless picture book to improve the writing ability of class VIII students MTs Surya Buana Malang. And the results show that the ability to write increases especially in terms of developing story ideas. Similarly, Rasyid (2009:56) implements a series of cartoons to improve the students' ability to write narrative of MTsN Nganjuk class XI. His research results show that serial cartoons can generate ideas and inspire students in imagining.

The purpose of this study is to find out how picture series is implemented to improve the students' ability to write narrative text. Learning activities in the classroom will include modeling on how to write stories and train students to write stories using picture series. Beside implementing picture series, the researcher also used process approach and peer review as the strategy to improve the students' narrative writing. Process approch is appropriate to make the students easier to develop ideas while peer review is to evaluate the students' understanding as well as to minimize mistake and error they probably made. Here are the steps in the implementation of picture series in writing narrative text: (1) brainstorming, the instructor initially helps the students in generating ideas by asking several questions related to the topic as well as the story of Cinderella and asking about the aspects of the story such as the characters, the setting of time and place, the plots, the conflicts, the solutions and the story messages so that students can automatically learn and understand the generic structure of the narrative text; (2) emphasizing, the instructor emphasizes the students on understanding the generic structure by repeating, explaining, completing and correcting the student's answers and writing them on the board; (3) observing, the instructor distributes a series of pictures to the student to be observed and then asked about the aspects of the story based on the picture series such as topics, characters, the settings of time/ place/ situation, conflicts, solutions, messages, etc.; (4) outlining, the student is guided by the instructor in making outline framework of the given series; (5) writing, students write a paragraph based on the outline that has been made.

\section{LITERATURE REVIEW}

Writing is the most complex skill compared to the other three skills. Writing can be difficult even in one's own language. In new language, writing can be even more difficult (Blanchard and Root, 2003:1). Oshima and Hogue (2007:15) state that the process of writing has roughly four steps. They are prewriting, organizing, drafting, and polishing; revising and editing. We need to encourage students to plan, draft and edit, even though this may be timeconsuming. 
According to Anderson and Anderson (1997:8), a narrative is a piece of text which tells a story and, in doing so, entertains or informs the reader or listener. Picture series which is arranged orderly does not only build the students' vocabulary but it also leads the students generate their ideas and organize their story. One way to have the students motivated in writing class is by choosing writing activities which have a chance of appealing to the students (Harmer, 2004:61). For instance, Teacher gives the students writing strategies that enable them to write easily and enjoy the activity like providing pictures to stimulate the students' eagerness to write a story. Pictures are really useful ways to prompt students into writing stories (Harmer, 2004:69). Picture series can trigger the students to start writing for it presents series of pictures in which students are usually interested.

\section{The Strategy of Teaching Writing Narrative Text Using Picture Series}

Creating a good and an interesting classroom atmosphere is a teacher's job. Teacher should be aware of students' need; the teacher should provide suitable techniques and interesting materials. The teaching strategy will be useful if it makes the students enjoy the learning and at the same time give more exposure to language input and more chance to practice the language (Rasyid, 2009:38). One of the strategies to be employed in the teaching of writing is by implementing picture series. Picture series is intended to encourage the students in overcoming the problems in writing. The procedure of implementing picture series in teaching writing is presented as follows

1. Picture series are introduced to the students. The teacher first help the students to generate ideas (brainstorming) by asking some questions relate to the topic. For instance, the teacher takes an example of 'Cinderella story'. Then she asks them some aspects like characters, setting of time and place, conflict, resolution and message. By identifying those aspects, the students automatically learn and understand the generic structures of narrative.

2. The teacher then emphasizes the students of their understanding on the generic structures of narrative by repeating, completing and correcting the students' answers and writes them on the board.

3. The teacher distributes the picture series to the students. She then asks them to observe the picture series. She invites the students to give responses and asks them to find any aspects/ events in the picture series, such as the topic, the characters, the setting of time and place, the objects, the conflict, the resolution, and the coda if any.

4. The students, guided by the teacher, make tentative outline about the picture series. 
5. Then they write the narrative paragraphs based on the outline and of course they are still guided by the teacher.

\section{RESEARCH METHOD}

Based on the research objectives above, the appropriate research design is Classroom Action Research (CAR). Burns (in Burns, 1999:30) defines action research as the application of fact finding to practical problem solving in a social situation with a view to improving the quality of action within it. In this study, the writer wanted to find a solution to the students lack in the ability to write narrative so that researcher implemented picture series as a strategy to improve students' ability in writing narrative text. CAR is conducted collaboratively in which the researcher working with teacher-collaborator in carrying out the research stages. Due to this qualitative research, the main methodological tools required are observation, description and data collection from various sources (Burns, 1999: 22).

In CAR, there is a cycle term which contains four important stages in the implementation of this research. The four stages are planning, acting, observing, and reflecting. At the planning stage, the researcher develops a lesson plan based on the result of problem identification. After the lesson plan is done, the next stage is implementation, make sure that each action done in the implementation is in line with the initial goal. The observations were conducted in conjunction with the implementation stage. At this stage collaborative research is conducted where the researcher acts as a classroom instructor and the original teacher-collaborator acts as the observer in charge of collecting the data regarding the implementation and the plan using the observed instrument that has been developed. And lastly the reflection which is the stage to process the result data from the observation. The data obtained are analyzed by researcher and collaborator regarding to success criteria established earlier. From the results of this reflection the researcher will know whether the strategy developed succeed or not. If it does not meet the criteria of success, then she should revise the strategy and go to the next cycle.

To find out the details of student problem in writing narrative, the researcher conducted preliminary study. Preliminary study is very important because it is a process to get the facts related to the problem being faced (Burns, 1999:37). From this, the researcher found some facts that students have difficulty in: (1) developing ideas into writing (70\% of students), (2) using appropriate words in English (65\%), and ( 3) using grammar that includes tenses, numbers, word order, articles, pronouns, and preposition (90\%). So, the researcher will focus on these three aspects in the evaluation of student writing. 
Here are the steps in the implementation phase: (1) brainstorming, initially the instructor helps the students in generating ideas by asking some questions related to the topic as well as Cinderella story and ask about the aspects of the story ie characters, setting of time and place, plot, conflict, solutions and story messages so that students can automatically learn and understand the generic structure of the narrative text; (2) emphasizing, from the responses given by the students during brainstorming, the instructor emphasizes students' understanding of the generic structure by repeating, explaining, completing and correcting student answers and writing them on the board; (3) observing, here the instructor distributes a series of pictures to the students to be observed and then asked about the aspects of the story based on the picture series such as topics, characters, settings of time/ place/ situation, conflicts, solutions, messages, etc ; (4) outlining, the student is guided by the instructor in making outline or framework of the given series; (5) guided writing, students write paragraphs based on outline that have been made; and (6) independent writing, students are first asked to write narrative text based on the picture series given in pairs and then they write the narrative text using the other picture series individually.

The observation stage is performed by the teacher-collaborator during the implementation process. She observes and collects data about whatever happens during the classroom implementation using the observation sheets, field notes and questionnaires at the last meeting. In the reflection stage, the data obtained at the implementation stage and observation are collected and analyzed referring to the criteria of success either in the form of products (students' writing) by evaluating them using scoring rubric as seen in table 3 and process (seen from observation sheet, field note and questionnaire). If the result meets the criteria of success, then the research stops in one cycle.

\section{FINDING}

The result of the study showed that the implementation of picture series could improve the students' ability in writing narrative texts, especially the result in Cycle 2 which the students' writing have reached minimum success criteria. In cycle 1 , the students' result has not met the criteria of success made, especially in term of language use. Some students got the score below the criteria so that the researcher should go to the following cycle and make over the plan she has made.

The students' success on the implementation of the research was determined by two assessments; the students' activities in writing and the final written product. The students' activities in writing were analyzed by using observation check-list, field notes, and questionnaires; while the final products were assessed by using scoring rubric. The data of the students' activities in 
writing resulted from observation check-list, field notes, and questionnaires were explained qualitatively as well as the students' final products.

The researh was done in two cycles involving 34 students as the subject of the study. In cycle 1, the strategy implemented was not successful yet because the students' writing products did not reach the criteria set as a whole because in terms of grammar and diction there are still some students who get score below the minimum criteria despite the fact, the students were actively involved during the learning process, even they were happy with the media of picture seriess and writing becomes more fun. Thus, the researcher had to fix the lack of students in terms of the use of grammar and diction so that researcher continued to cycle 2.

In cycle 2, Several findings were obtained from the analysis of teaching and learning process and student learning outcomes. First, the learning procedure was carried out according to the plan. Second, the students were active during the learning process even they were very interested in the media provided. Finally, the results of the students' writing have reached minimum success criteria, especially in organization and diction. In addition, most students have improved their writing in terms of grammar.

\section{DISCUSSION}

\section{CYCLE 1}

In cycle 1 , the researcher used two picture series a fairy tale "Cinderella" from internet and a fable "The Lion and the Mouse" taken from A Jungle Story Book. The "Cinderella" is used during modeling while "The Lion and the Mouse" is used during the training phase. Picture series consists of 8 images in A4-sized paper. Cycle 1 consists of 3 meetings with each for 100 minutes.

In the implementation of teaching and learning process, the researcher acts as instructor and the teacher-collaborator as observer. At the first meeting, before entering the main activity the instructor brainstorms to elicit students' opinions and thoughts by asking questions related to topics such as: "Have you ever heard / read a story of Malin Kundang?", "What does it tell about?", and "Who are the main characters?", "When and where did it happen?", and "How is the plot of the story?". After getting answers from the students, the instructor explores students' knowledge and understanding of the structure of the narrative text by asking them to mention it one by one then write it on the board. Then the instructor repeats the structure of the text completely and concludes it to (1) Orientation: introduces the character, setting the place and time, (2) Complication: the emergence of conflict and climax, and (3) Resolution: solutions and messages). In addition, the instructor stresses that in the narrative text, the tenses used are past tense.

In the modeling stage, the instructor displays a picture on the LCD screen that is a "Cinderella" series and discusses it together. First of all, the instructor 
asked "what story you can see from this picture?" And simultaneously the student replied "Cinderella". After that it is followed by questions about characters, setting time and place, objects and action verbs that are appropriate to represent each series of pictures. Having mentioned the structure of the text, the instructor led students make outline. Outline is a design for writing text. Here the students are asked to write $1-2$ sentences that can represent each picture of a total 8 picture series. The instructor gives an example first by creating a sentence that represents the first picture on the board. The students are then asked to write sentences that reflect the second picture until the last picture.

From the outline written on the board, the students in pairs are asked to develop it into 3 paragraphs with paragraph 1 containing "orientation" paragraph 2 containing "complication" and paragraph 3 containing "resolution". Students are free to ask and consult the instructor during the process of developing paragraphs and they can open a dictionary to find out several dictions. Before the meeting ends, the students collect the results of their writing to the instructor to get correction.

The training stage is done at the second and third meetings. Firts, the instructor distributed the students' writing results in the previous meeting so that they understood and learned from their mistakes to write the next narrative text. Then the instructor distributed picture series "The Lion and the Mouse" to the students and in pairs they were asked to observe the narrative structure of the picture. In addition, students are asked to mention any possible word that is considered difficult and write it on the board so they can use it in writing later. The researcher conducted collaborative writing as it can also improve students' motivation and self-confidence to write a foreign langauge composition. This is in line with Sukirman (2016:43) that collaborative writing enhance students' critical thinking as well as their motivation. Moreover, it also can encourage the students to write actively in writing process because of the peer review benefits (Soraya, 2016:66).

Next the students made an outline to be developed into paragraph. During this process, the instructor walked around the class monitoring and helping the students if they face difficulties. The instructor reminded the students about the selection of words and the use of tenses because these two mistakes were commonly found in the modeling session. Ten minutes before the lesson ended, the students were asked to review their narrative text in terms of organization, diction and grammar.

The results of observation showed first, the instructor found that the lesson plan has covered the learning objectives and the learning steps, the materials and writing activities are relevant to the objectives, and in terms of the learning process the instructor has explained the learning objectives before entering the 
main activities, exploring the students' knowledge about narrative text as well as guiding students in finding topics, writing and editing paragraphs. From the students' side, they always respond questions asked by the instructor enthusiastically starting from brainstorming until the end of learning. They are not reluctant to give opinions and to answer the question even when it was uncorrect. The students did the instuction well like when they were asked to watch the picture series, they did well without making a crowd or chatting each other.

Similar to the observer's field notes, the information obtained showed that the students seemed to be excited and enthusiastic about the picture series in writing narrative text. From the instructor's side, the observer writes that the instructor has created a series of fun and effective writing activities such as guiding students to make outline first. In addition, the observer also left a note to the instructor which was to increase her voice volume so that could be heard by the entire class..

The students' writing results were analyzed and corrected by instructor/ researcher and teacher-collaborator. The results of the students' writing in cycle 1 have not reached the success criteria set out in the aspects of grammar and diction use. However, the results of the students' writing on this 1 st cycle were better than those on the preliminary study. Here is one sample of student writing.

\section{THE LION AND THE MOUSE}

Long time ago, lived a lion in the jungle. One day the lion slept under a tree near his den. And then a mouse came close the lion. And the mouse climbed and danced didn't feel guilty. So, the lion woke up and he feel there something on his head. The lion was angry and he caught the mouse. The mouse very scary because the lion threaten to kill him. So, the mouse asked permission and the lion forgive him. And the mouse left the lion until the lion lonely.

The next day, the lion trapped in the hunter's net. And he tried hard to get out from the hunter's net, but he can't. And then the lion roared loudly until the mouse heard the lion's voice. The mouse remembered that the lion's voice. So, the mouse ran quickly to help the lion.

After arriving, the mouse come close the lion and climb to the lion's body. The mouse bit the net with his sharp teeth until the lion was free. Finally, the mouse said "don't ever underestimate others because every single creature has a good point".

$$
\text { By: I\&N }
$$

The text above is an example of students' writing which is poor in grammatical and diction aspects. There are some errors in grammar especially the use of past tense form. An example of unappropriate use of diction is "until the 
lion lonely" which is should be alone. The following table shows the student's writing level in cycle 1 .

Table 1 Student's writing level on cycle 1

\begin{tabular}{cccc}
\hline & Organization & Diction & Grammar \\
\hline Level 1 & 0 & 0 & 0 \\
\hline Level 2 & 0 & 4 & 12 \\
\hline Level 3 & 11 & 10 & 5 \\
\hline Level 4 & 6 & 3 & 0 \\
\hline
\end{tabular}

The table above illustrates that in terms of organization, no group reaches level 1 and 2, eleven groups reach level 3 and six groups reach level 4. In terms of diction, no group reaches level 1, only four groups reach level 2 and 4, and ten groups reached level 3, and 3 groups reached level 4. In terms of grammar, no groups reached level 1 and 4, twelve groups reached level 2, and five groups reached level 3. Thus, the researchers could conclude that the students' writing result in cycle 1 has not met the success criteria.

From the results of cycle 1 discussed above, it can be concluded that: (1) learning procedures have been implemented in accordance with the lesson plan, (2) the students are actively involved during the learning process, even they are happy with the media of picture seriess and writing becomes more fun. This is in line with the research findings of Gutiérrez, K.G.C. et al. (2015:59) that Pictures series technique made more effective the Process approach implemented in the groups., and (3) students' writing results can not reach the criteria set as a whole because in terms of grammar and diction there are still some students who get score below the minimum criteria. So, here researchers still have to fix the lack of students in terms of the use of grammar and diction so that researcher has to continue to cycle 2 .

\section{CYCLE 2}

In cycle 2, the researcher used picture series that were also taken from A Jungle Story Book "The Hare and the Tortoise" and "The Ant and the Grasshopper". The first picture series, The Hare and the Tortoise, were given to students in pairs. The instructor scrambled the pictures and the students arranged them in order. Then they must stick them on a paper so that they become a series of pictures reflecting a complete story. And the second picture series "The Ant and the grasshopper" is given to students individually. Each student must write a story based on the picture series.

In cycle 2 the researcher needed 4 meetings with details of the first two meetings used for collaborative writing sessions, third meeting for individual 
writing, and fourth meeting for peer review and revision. In collaborative writing, the first meeting focuses on making outline and paragraphing, and the second meeting the students did peer review. And at the third meeting each student writes the text independently, and the last meeting they conducted peer review and revision before collecting their final writing.

At the first meeting, the instructor showed the results of the students' writing on cycle 1 . The instructor and the students together discussed the mistakes that many students made in their writing. Students were reminded of the structure of narrative text and grammar in narrative writing. The instructor showed some errors to be corrected by the student. Once they understood the mistakes made, the instructor began the main activity of collaborative writing. Students in pairs were given a series of random pictures so they have to sort them out first. Then the students were asked to mention the difficult vocabulary that can be used when writing later. Furthermore, students made outline 1-2 sentences for each picture. After that, students developed the outline into a whole paragraph. In the second meeting, the students focsed on peer reviewing and editing where students exchanged their writings to be observed and commented on for errors and mistakes. Students were allowed to ask the instructor or open the dictionary if necessary. Having completed the peer review session, the students' writing then returned to the owner for editing and revision to yield better writing products..

The third and fourth meetings were the culmination of a series of writing activities, namely individual and independent writing, no instructor guidance and assistance. Before picture seriess were distributed to each student, the instructor again reminded the students about the structure of the narrative text and its grammar. After all of the students were ready and no more questions, the instructor gave the picture series "The Ant and the Grasshopper". The students were asked to make an outline first within 20 minutes before compiling it in a complete paragraph. Five minutes before the end of the class, they were asked to collect their writing. And at the last meeting the instructor asked the students to do peer review individually. Then the writings were returned back to their owners to be revised before finally collected to the instructor. This peer review section has a big role in improving the students' performance in writing narrative, as stated by Baker, K. M. (2016:189) that peer review has the capacity to improve students' learning in a course, to help them develop self-assessment skills, and ultimately to move them toward becoming independent thinkers and writers.

The results of the observations during the implementation of cycle 2 showed that: (1) the series of learning activities were accordance with the lesson plan prepared, (2) the material and the writing assignment were relevant to the learning objectives; (3) the students were actively involved during the learning process; working professionally either in groups / pairs or individuals, and (5) all 
students were happy and encouraged by the picture series in the writing activities. So it can be concluded that the students showed positive attitude during the learning process and the series of learning has been implemented well as planned.

The results of students' writing on cycle 2 showed improvement in all aspects, organization, diction, and grammar. The improvement can be compared from the results of writing in cycle 1 , cycle 2 collaborative writing, and individual writing cycle 2 . Here's an example of student writing on cycle 2 of collaborative writing.

The tortoise can beat the hare. The hare then regretted because $\sqrt{ }$ (he had) underestimated the tortoise and teased the tortoise too.

There were two errors in the text above. First, students write the word can instead of could because it should be past tense. Second, because underestimated that there should be a word he had between the two words. The following table shows the writing level of students in cycle 2 collaborative writing.

Table 2 The level of students' writing in cycle 2 (collaborative writing)

\begin{tabular}{cccc}
\hline & ORGANIZATION & DICTION & $\begin{array}{c}\text { LANGUAGE } \\
\text { USE }\end{array}$ \\
\hline LEVEL 1 & 0 & 0 & 0 \\
\hline LEVEL 2 & 0 & 0 & 0 \\
\hline LEVEL 3 & 9 & 13 & 15 \\
\hline LEVEL 4 & 8 & 4 & 2 \\
\hline
\end{tabular}

And below is an example of students' writing on individual writing session where students use the word think that should be thought because it shoud be past tense.

He think that the ant had a large supply of food.

The result of the students' writing on cycle 2 shows improvement because it found less mistake than writing in cycle 1.

Table 3 The level of students' writing in cycle 2 (individual writing)

\begin{tabular}{cccc}
\hline & ORGANIZATION & DICTION & $\begin{array}{c}\text { LANGUAGE } \\
\text { USE }\end{array}$ \\
\hline LEVEL 1 & 0 & 0 & 0 \\
\hline LEVEL 2 & 0 & 0 & 0 \\
\hline LEVEL 3 & 23 & 20 & 27 \\
\hline LEVEL 4 & 11 & 14 & 7 \\
\hline
\end{tabular}


There were several findings obtained from the analysis of teaching and learning process and student learning outcomes. First, the learning procedure is carried out according to the plan. Second, the students are active during the learning process even they are very interested in the media provided. Finally, the results of the students' writing have reached minimum success criteria, especially in organization and diction. In addition, most students have improved their writing in terms of grammar. The enhancement of the students in writing ranging from preliminary study, cycle 1 , cycle 2 (collaborative writing) until they can write individually and independently in cycle 2 can be seen in the following table.

Table 4 the average score of the students' writing in each category

\begin{tabular}{ccccc}
\hline CATEGORIES & $\begin{array}{c}\text { PRELIMINARY } \\
\text { STUDY }\end{array}$ & $\begin{array}{c}\text { CYCLE } \\
1\end{array}$ & $\begin{array}{c}\text { CYCLE 2 } \\
\text { (COLLABORATIVE) }\end{array}$ & $\begin{array}{c}\text { CYCLE 2 } \\
\text { (INDIVIDUAL) }\end{array}$ \\
\hline DICTION & 2.4 & 3.05 & 3.25 & 3.4 \\
\hline $\begin{array}{c}\text { LANGUAGE } \\
\text { USE }\end{array}$ & 1.9 & 2.5 & 3.1 & 3.2 \\
\hline ORGANIZATION & 2.6 & 3.3 & 3.45 & 3.5 \\
\hline
\end{tabular}

\section{CONCLUSION}

Based on the reflection of the two cycles and the results of the research that has been presented, it can be concluded: (1) the procedure in the implementation of picture seriess in writing narrative text is: brainstorming, the instructor guides the students in generating ideas by asking several questions related to the topic narrative text); emphasizing, the instructor emphasizes the students understanding the generic structure and language features by repeating, explaining, completing and correcting student answers and writing them on the board; observing, the instructor distributed a series of pictures to the students to be observed and then asked about the aspects of the story based on the picture series such as topics, characters, settings of time/ places/ situations, conflicts, solutions, messages, etc .; outlining, where the student is guided by the instructor in making outline of the given picture series; writing, that is writing paragraphs based on outlines that have been created collaboratively and then individually. In the process of writing, there is also peer reviewing (2) the teaching and learning process in the implementation of the picture series can be done effectively and smoothly, (3) the students are happy with the picture series because they are interesting, easy to understand and can help them to develop ideas, (4) picture seriess can improve the ability of students in writing narrative especially in terms of organization, (5) results of CAR has reached the criteria of success both the attitude of students during the learning process and students' writing that have met the minimum criteria in all aspects; organization, diction, and language usage. 
The results of this study are expected to contribute to some parties. First for instructors/ teachers in teaching students writing narratives, they can apply such media or picture series or by applying a series of writing processes such as brainstorming, outlining, drafting, editing, etc. Second for further research, researchers can implement picture seriess for other language skills such as speaking or for writing other genres such as procedure text.

\section{REFERENCES}

Anderson, A. \& Anderson, K. (1997). Text Types in English 2. South Yarra: Macmillan Education.

Ariani, F. (2010). Efektifitas Penggunaan Gambar Berseri Dalam Pembelajaran Menulis Naratif Mahasiswa Semester III Program Studi Pendidikan Bahasa Prancis Jurusan Bahasa dan Sastra Asing Fakultas Bahasa dan Seni Unnes. Unpublished Thesis: State University of Semarang

Baker, K. M. (2016). Peer review as a strategy for improving students' writing process. Active Learning in Higher Education, Vol. 17(3) 179-192.

Blanchard, K. \& Root, C. (2003). Ready to Write. New York: Pearson Education.

Burns, A. (1999). Collaborative Action Research for English Language Teachers. Cambridge: Cambridge University Press.

Gutiérrez, K.G.C. (2015). Using Pictures Series Technique to Enhance Narrative Writing among Ninth Grade Students at Institución Educativa Simón Araujo. English Language Teaching; Canadian Center of Science and Education. 8 (5).

Harmer, J. (2004). How to Teach Writing. New York: Pearson Education

Hasanah, Y. A. (2008). Implementing Picture Sequences to Improve Students' Ability in Writing Narrative Texts. Unpublished Thesis: State University of Malang

Nitalinawati, S. (2009). Using Wordless Picture Books to Improve Students' Ability in Writing Narrative Texts at MTs Surya Buana Malang. Unpublished Thesis: State University of Malang.

Oshima, A. \& Hogue, A. (2007). Introduction to Academic Writing. New York: Pearson Education.

Rasyid, A. (2009). Utilizing Cartoon Series to improve the Writing Narrative Text Ability of the Grade-Nine Students of MTsN Nganjuk. Unpublished Thesis: State University of Malang.

Soraya, K. (2016). The Effectiveness of Collaborative Writing Strategy (CWS) in Writing Lesson Regarded to The Students' Creativity. Lingua Cultura, 10(2). 63-67. http://dx.doi.org/10.21512/lc.v10i2.898

Sukirman. (2016). Using Collaborative Writing in Teaching Writing. Langkawi: Journal of The Association for Arabic and English, 2(1): 33-46

Widiati, U. \& Cahyono, B. Y. (2006). The Teaching of EFL Writing in the Indonesian Context: The State of the Art. Jurnal Ilmu Pendidikan, 13(3):139-150.

Wright, A. (1992). Pictures for Language Learning. Cambridge: Cambridge University Press. 